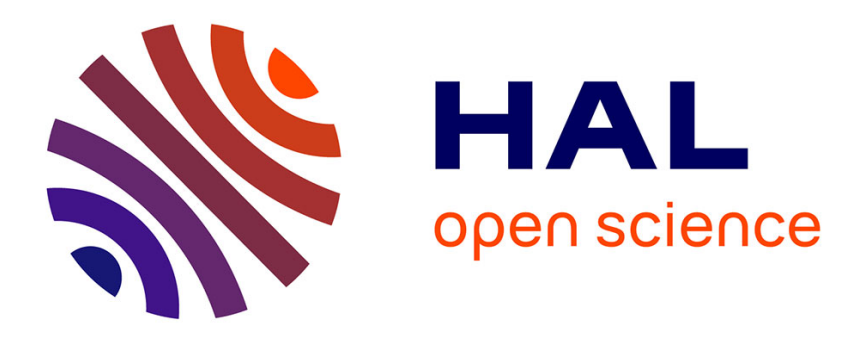

\title{
Rationality, behavior, institutional and economic change in Schumpeter
}

Agnès Festré, Pierre Garrouste

\section{To cite this version:}

Agnès Festré, Pierre Garrouste. Rationality, behavior, institutional and economic change in Schumpeter. Journal of Economic Methodology, 2008, 15 (4), pp.365-390. 10.1080/13501780802507222 . halshs-00274163

\section{HAL Id: halshs-00274163 \\ https://shs.hal.science/halshs-00274163}

Submitted on 5 Aug 2009

HAL is a multi-disciplinary open access archive for the deposit and dissemination of scientific research documents, whether they are published or not. The documents may come from teaching and research institutions in France or abroad, or from public or private research centers.
L'archive ouverte pluridisciplinaire HAL, est destinée au dépôt et à la diffusion de documents scientifiques de niveau recherche, publiés ou non, émanant des établissements d'enseignement et de recherche français ou étrangers, des laboratoires publics ou privés. 


\title{
Rationality, behavior, institutional and economic change in Schumpeter
}

\author{
by Agnès Festré and Pierre Garrouste
}

\begin{abstract}
In 1940 Schumpeter wrote a paper entitled: "The Meaning of Rationality in the Social Sciences", which was intended as a contribution to one of the meetings of a seminar including Talcott Parsons, Wassily Leontief, Paul Sweezy and other Harvard scholars, that he initiated. In this paper Schumpeter develops thoroughly his own conception of rationality in economics. First, this paper is interesting in itself because it relates to contemporary methodological debates on rationality in the social sciences. Second Schumpeter's conception of rationality is linked to his methodological background (both individualistic and holistic), which is rooted in his economic sociology and explains the relationships he stresses between individual behavior and collective entities. In this contribution we present the arguments developed by Schumpeter in his 1940 paper and analyze the reason why his notion of rationality can be seen as a key component of his conception of economic and institutional change.
\end{abstract}

JEL Classification: B25 - B31 - B52 - D02 - Z19 


\section{Introduction}

In 1940 Schumpeter wrote a paper entitled: “The Meaning of Rationality in the Social Sciences." This paper was written for one of the meetings of a interdisciplinary group ${ }^{1}$, referred to in the following as the Harvard Seminar that Schumpeter initiated, including the sociologists Wilbert E. Moore and Talcott Parsons, the economists Wassily Leontief, Paul Sweezy and Gottfried Haberler, the psychologist McGrannahan and other Harvard scholars (Swedberg, 2006). The multidisciplinary context of the Harvard Seminar certainly contributed to give it a strong methodological complexion. In his 1940 paper, Schumpeter indeed develop his own conception of rationality in economics (and not so much in the broader field of social sciences as the title of the paper suggests) more from the standpoint of abstract methodology rather than economic analysis. Interestingly, his methodological arguments turn out to anticipate some important debates concerning the defense of the producer's maximization assumption (Alchian, 1950; Friedman, 1953), even if Schumpeter is very reluctant to use the 'natural selection' analogy, which makes his conception of rationality very topical. Second, Schumpeter's conception of rationality needs to be linked with his overall methodological approach, and in particular to the peculiar role played by economic sociology, which implies a both individualistic and holistic conception of economic behavior and institutional change. In fact our paper is a contribution to the idea that "it can be argued that Schumpeter's synthesis presented a network of useful knowledge organized by the criterion of coherence." (Shionoya, 1997, 310).

The remainder of this article is organized as follows. In section 1 we present the arguments developed by Schumpeter in his paper on rationality. Section 2 is an attempt to relate Schumpeter's notion of rationality to the specific role played by economic sociology regarding economic behavior as well as the relationships between individuals and collective or social entities. In section 3 we examine how and why it is possible to champion an institutionalist interpretation of Schumpeter's theory of economic evolution.

\section{Schumpeter's conception of rationality}

At the very beginning of his paper, Schumpeter defines, following Kirchhoff's definition of mechanics, what he considers being a science: "I shall define science in general 
as the endeavor to describe phenomena we happen to be interested in, in the way most economical with reference to an assigned degree of accuracy.” (Schumpeter [1940] 1991, 316). The idea of the most economical way of description is an application of Occam's razor principle, which, according to Schumpeter, should not imply that logical reasoning should be confined to verifiable "facts" or to empirical cognition as the following quote from our author illustrates: "if the hypothesis that planets are moved by angels opened the shortest way to describing their motion, there could be no objection to it on grounds of scientific rationality." (ibid pp. 316-17) ${ }^{2}$

Schumpeter emphasizes that "both the scientific attitude and that aversion to extraempirical cognition are, of course, sociologically related.” (ibid, 317). More precisely, he points out that "[t]hey are both the products of 'rationalist' civilizations” but should logically be kept distinct” (ibid). This conception of science lends support to the idea that science is historically determined and is not necessarily an empirical enterprise. He also stresses that " $[\mathrm{s}]$ cientific rationality is also relative to the horizon of the analyst, that is, to the information and mental equipment at his command. What behavior is [therefore] rational for a given analyst or observer can only be determined if we know what he knows.” (ibid). This idea of 'historical relativism' is recurrent in Schumpeter's analysis and has also to be related to the distinction he makes between 'rationality of the method' and 'rationalism' (see Figure 1). This distinction emphasizes the potential discordance between what can be regarded as rational from the viewpoint of the method that is used at a given time and how this method is looked back retrospectively by a current observer ${ }^{3}$. This aspect can also be related to Schumpeter's method of analysis, as developed in the introduction of his History of Economic Analysis. Schumpeter, indeed, emphasizes that sociological and historical matters should constitute fully-fledged components of economic analysis.

These methodological remarks concern the scientific procedure as it may apply to every kind of science. Moreover, from the viewpoint of rationality, they only relate to what Schumpeter refers to as "the rationality of the observer", i.e., the rationality of the analyst (see Figure 1). Schumpeter's aim, however, is to tackle the problem of rationality in the social science, and in this perspective, he contrasts the former type of rationality with what he calls the "rationality of the observed" and highlights several problems related to the latter ${ }^{4}$.

First, Schumpeter raises the question of the status to be given to the ends of any individual action ${ }^{5}$.. This issue is taken up by Schumpeter. In compliance with Paul Sweezy, he emphasizes the idea that we have to face an infinite regress when we try to define ultimate ends, just because value judgments need to be based on other value judgments. He however 
considers that "it is quite true that ordinarily we do not meet with ultimate values and that the valuations we do meet are usually intermediate ones, i.e., really refer to means to an end not itself under discussion.” (ibid, 318).

Second, Schumpeter stresses the differences and relations between the rationality of the analytical procedure and the rationality of the result. Accordingly rationality and truth are not congruent even if there is a relation between them. It is interesting to note that he seems to disagree with Friedman's argument (1953) that is rooted in the 'if then' logical properties ${ }^{6}$ when he indicates that rationality of procedure does not warrant the rationality of the result "unless we include correctness and adequacy of both the material and the equipment at the command of the analyst which we cannot do if we admit varying horizons.” (ibid, 319). Schumpeter considers however that rationality of procedure is a necessary (but not sufficient) condition for the rationality of the result.

Third, he emphasizes the idea that "rationality in the social sciences emanates from the analyst” (ibid, 319). More precisely, what Schumpeter means by this statement is that, in contrast to other sciences, social sciences are characterized by the fact that the analyst does not confine himself to draw causal relationships between objects and elaborate concepts based on these relationships in order to build theories or models, but that he must, in many cases ${ }^{7}$, also understand the meaning of individual actions and, therefore, set up norms of behavior (ibid, 322) ${ }^{8}$. In other words, the analyst is compelled to assume some kind of rationality in the real economic or social world even if true individuals do not display or do not conform to such rationality. This point is exemplified by the following quotation: "we will emphasize at once that this observer's rationality has in itself nothing whatever to do with the presence or absence of rationality in the human types or human actions observed, or even with the applicability of the concept of rationality to the subject under investigation” (ibid, 319) ${ }^{9}$.

Schumpeter illustrates this point by referring to the classic case of monopoly and to its traditional modeling by means of the marginal revenue and marginal cost curves. He highlights that the optimization programme does not need to be actually followed by a businessman in order for the maximization procedure to hold: “(...) nothing of this is necessary for the model to have sense and to be useful. For a man's behavior may conform to it and be economically described by it, even if its contents are as foreign to his mind as the law of gravitation is foreign to a stone.” (ibid, 321) ${ }^{10}$.

Such a procedure, ending in a model, provides a standard and then a description. This standard can thus be used to compare actual behavior or it might. It helps "to describe actual behavior by giving its rationale” (ibid, 322). Following Schumpeter’s terminology, this kind 
of rationality can be described as “objective rationality (rationality in the object) seen through the rationality of the observer.” (ibid, 322).

In sum, Schumpeter's conception of rationality in the social sciences articulates two levels of rationality of the observer. The first one, i.e., the "rationality of the observer", defines the usual rational procedure in sciences in general, while the second one emphasizes the specificity of social sciences, i.e., the fact that the analyst must set up norms of behavior that relate to the "rationality of the observed", but that are the emanation of the analyst, in his endeavor to understand (in the German sense of Verstehen) the logic of individual actions. Schumpeter's distinction between the 'rationality of the observer' and the 'rationality of the observed' also reveals the singularity of his methodological approach. In particular, Schumpeter's conception of rationality is not based on the idea that there is some 'essential' rationality lying behind the existence of social reality, namely, behind the actions of concrete interacting men. His conception is therefore far from Menger's, according to which the exact orientation of research in economics has to reveal the essence of social phenomena ('exact types' and 'exact relationships' between them) that is hidden behind real phenomena ('real types' and 'real relationships' between them). For Schumpeter, there are sociological as well as historical dimensions that determine the ways the observer casts some rationality on the observed. This assumption is essential and underlies Schumpeter's conception of rationality in the social science. Several remarks by Schumpeter confirm this interpretation.

First, as already emphasized above, Schumpeter claims that if the observer "has succeeded in 'understanding' the end of the observed and if he has correctly set out its implications then he has (...) derived a 'norm' which is 'valid', whether there are any facts conforming to it or not (whether it is 'verified by facts' or not)". That this norm is "visualized as something capable of being realized" is sufficient condition of rationality at this stage. It corresponds to what Schumpeter calls "rationality in the object", a kind of rationality that distinguishes social sciences from physical sciences or sciences in general (ibid, 323) ${ }^{11}$.

Second, Schumpeter reminds us that "the observer needs to understand the end even if he does not share it” (ibid, 324) ${ }^{12}$. This remark is clearly related to the idea of historical or sociological relativism in Schumpeter's methodological approach. Schumpeter here stresses the problem of the "infinite variety of cognate ends", which often bias the judgment of the observer as regards the rationality of the observed: “[m]any types of behavior are looked upon 
as irrational (not conforming the schema of rational action), and the range of rationality in action is in consequence often underestimated because the tests of rationality have been made by means of models that failed to fit, not because they are rational but because they did not capture the right type of Zweckrationalität [rationality of end].” (ibid, 324). This assertion relates to Schumpeter's statement that "rationality in social sciences emanates from the analyst” (ibid, 319). At first sight, one may consider that it is contradictory to suppose, on the one hand, that the analyst, by means of the description of the world he proposes, does create rationality and to consider, on the other hand, that he is likely to fail in the way he describes the world because he misses some aspects of individuals' rationality. This contradiction is however removed if one interprets correctly Schumpeter's conception of rationality as a multi-level analysis of rationality (see below).

Third, Schumpeter calls the reader's attention to the problem of conflicting ends (ibid, 324). This issue is essential not only because it anticipates some recent results ${ }^{13}$ in terms of utility functions or some of the developments of both the so-called Public Choice approach and agency theory, but also because it foregrounds the fact that individuals usually pursue several and often conflicting ends. Schumpeter gives two instances of this problem, referring to conflicts between the interest of the executives and the interest of a business corporation or between the interest of the working class and the interest of trade union officers (ibid, 325). It also relates, as we will emphasized in the next section, to Schumpeter's analysis of social classes, more peculiarly to his distinction between self-interest and class-interest. This feature also clashes with the usual Austrian perspective and, again, reveals the specificity of Schumpeter's overall approach to economic theory.

Fourth, Schumpeter stresses again the distinction between rational behavior and rational results. The case of economic crises, which Schumpeter refers to, exemplifies the possibility that, even though individuals do act rationally, the collective result may be entirely irrational. It should be noted that this feature is perfectly in line with the usual Austrian assumption of 'unintended consequences of voluntary actions'. Moreover, it fits with contemporary dynamic models that show that evolutionary processes can end up in suboptimal outcomes.

Fifth, Schumpeter insists on the necessity, in order for the analyst to evaluate the right rationality of end, to "put himself' into places far distant from his time place and social location" or "to transplant himself into another cultural world" (ibid, 325). Here again, the idea of historical and sociological relativism is foregrounded by Schumpeter and exploited as an argument to criticize Max Weber's denial of ancient Chinese rationality ${ }^{14}$. 
All these remarks concern the double dimension of the rationality of the observer (scientific rational procedure and rationality in the object) in the social sciences. However, Schumpeter does not neglect the existence of a third type of rationality, namely "subjective

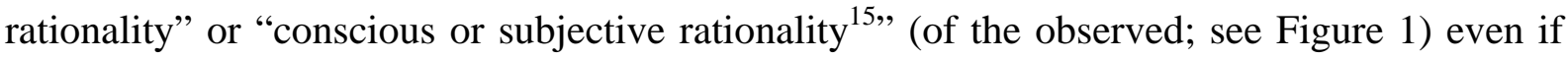
he gives the reader the impression that he treats it as secondary. Two reasons may explain Schumpeter's attitude.

First, he argues on logical grounds that objective rationality (or rationality in the object) does not imply a one-to-one relation to the subjective one. First, "it is not necessary that the subjective rationality of actors works in the same way as the rationality of the observer” (ibid, 328). The case of the Cournot-Marshall monopoly is a good example of this absence of conformity. Second, "it might be objective that whatever we may find out by means of subjective rationality can always be embodied in our 'objective rational' models so that there is no reason after all to stress what the subjective rationality might be in the actors we observe.” (ibid, 328)

Second, in compliance with his 'institutionalist' conception of individual behavior (see above), he considers that to focus on subjective rationality is to overestimate the range of conscious and deliberate behavior. He refers in this respect to Marshall and Wicksell, stating that the way they expressed themselves suggests "excessive reliance on subjective rationality" (ibid, 336). In other terms, according to Schumpeter, workers in the social science often go too far by assuming implicitly or explicitly that individuals "are themselves actuated by clearly perceived motives, and regulate their behavior with conscious rationality working in the full daylight of their ego's” (subjective rationality), whereas the supposedly "conscious motives that a man will tell himself and others are largely [ex post] rationalizations of unconscious or innate impulses.” (ibid, 326).

Nevertheless, Schumpeter does not dispose of the problem of subjective rationality and of its relation with objective rationality, in particular, the question as to whether subjective rationality is in conformity with objective rationality or not.

For him, the distinction between objective and subjective rationality ${ }^{16}$, and more precisely, the procedure which consist in focusing on subjective rationality, can be relevant, from a heuristical viewpoint, when it permits to gain analytical control on the phenomena we observe and to avoid redundant assumptions as regards individual behavior. It is also valuable when one uses rational schemata as 'interpretative schema'. In these conditions, the ultimate objective finality (as founded on the speculative knowledge (Erkenntnisgrund) of the observer 
becomes an 'explanatory hypothesis' of the actual individual's behavior (Realgrund). If for any reason this hypothesis is not justified, then the conformity between subjective and objective rationality becomes a puzzle to be solved. Symmetrically, conformity between objective and subjective rationality permits to establish diagnostic as well as previsions inasmuch as people actually behave like the observer think they do. It is then possible for the observer to perfectly anticipate the way people will behave and accordingly the results of their behaviors.

But the relevance of subjective rationality to analysis stands out more clearly in cases in which rational schemata do not fit. In this case, i.e., when rational schemata based on objective rationality fail to capture adequately actual behavior, “(...) deficiency in subjective rationality may directly be the reason we seek, or one of these reasons”. It is nevertheless true that “(...) investigation of subjective rationality may put us on to the track of other reasons and even help us to identify the right 'objectively rational model'.” (ibid, 329).

Schumpeter's conception of rationality can be summarized by emphasizing the two levels that it involves.

The first level is provided by the distinction between two kinds of rationality: the 'rationality of the observer' and the 'rationality in the observed' (see level I/II on Figure 1) ${ }^{17}$. This first level permits him to establish the borderline between natural sciences, on the one hand, and social sciences, where the relationships between the analyst (the observer) and the social reality (the observed) become fundamental, on the other hand. In other terms, Schumpeter's overall schema of rationality is to be considered as a general framework of rational models that is not confined to the problem of rationality in the social sciences, but also to include rational models belonging to the natural sciences. This is exemplified by the fact that in many passages of his paper, Schumpeter analyzes the differences between natural (mostly physics) and social sciences (mostly economics). As we have emphasized, this first distinction also underlines the specificity of social sciences with respect to rationality, i.e., the fact that in the social sciences the observer needs to be 'rational' in a double sense: he has to make use of logical reasoning in order to set up models, but also has to understand the ends that individuals pursue. Social sciences share however the characteristics and then the properties of rational schemata in the natural sciences, namely, the necessity to offer an accurate description of the (social) reality, the use of logical tools in order to develop arguments and historical and sociological relativism. Those elements that are common to both 
social and natural sciences are located on the left of the dotted bold vertical line on Figure 1, while on the right side of this line, the specificity of the social sciences in terms of rationality is sketched out .

The second level of Schumpeter's analysis of rationality concentrates on rationality in the social sciences per se. This level now consists in the distinction between 'objective rationality' and 'subjective rationality' (this level is identified by the continuous ellipse and the distinction by means of the dotted fine vertical line on Figure 1). This level of analysis permits Schumpeter to stress the importance of the notion of subjective rationality and its relationships with the notion of objective rationality. The fact that this distinction corresponds to the one made, respectively, between consciousness and subconsciousness is perfectly justified since, as we have underlined, 'objective rationality' is assigned to individuals' behavior by the analyst. In other words, the rationality of the observed is seen through the rationality of the observer. At the opposite, 'subjective rationality' is necessarily conscious since it is an understandable and explicit account (in terms of means and ends) of the effective behavior of individuals ${ }^{18}$. In other words, individuals are 'objectively rational' when the analyst correctly (that is logically or on the basis of data) describes their behavior even if individuals do not know that they 'have' to behave in this way; while they are 'subjectively rational' when they have 'good reasons' to behave as they actually do, and that those 'good reasons' can be made explicit.

We shall now investigate in more details Schumpeter's conception of rationality relates to his overall methodological approach and in particular, to the role he ascribes to economic sociology as far as individual economic behavior and its relation to social entities are concerned.

This inquiry will be carried out in two successive steps. First, we will concentrate on Schumpeter's economic sociology by focusing on its connection with economic behavior as well as the relations between individuals and collective entities such as social classes. We will also consider Schumpeter's analysis of the evolution of social structures in order to show how it can be connected to the issue of conflicting ends as developed in his 1940 article on rationality (section 2).

The second step will consists in an attempt to sketch out a preliminary picture of how institutional change may occur in Schumpeter's overall framework, by focusing, in this perspective, on how it can be related both to his conception of rationality and his dynamic analysis of social classes (Section 3). 
Rational schemata or models (interpreted)

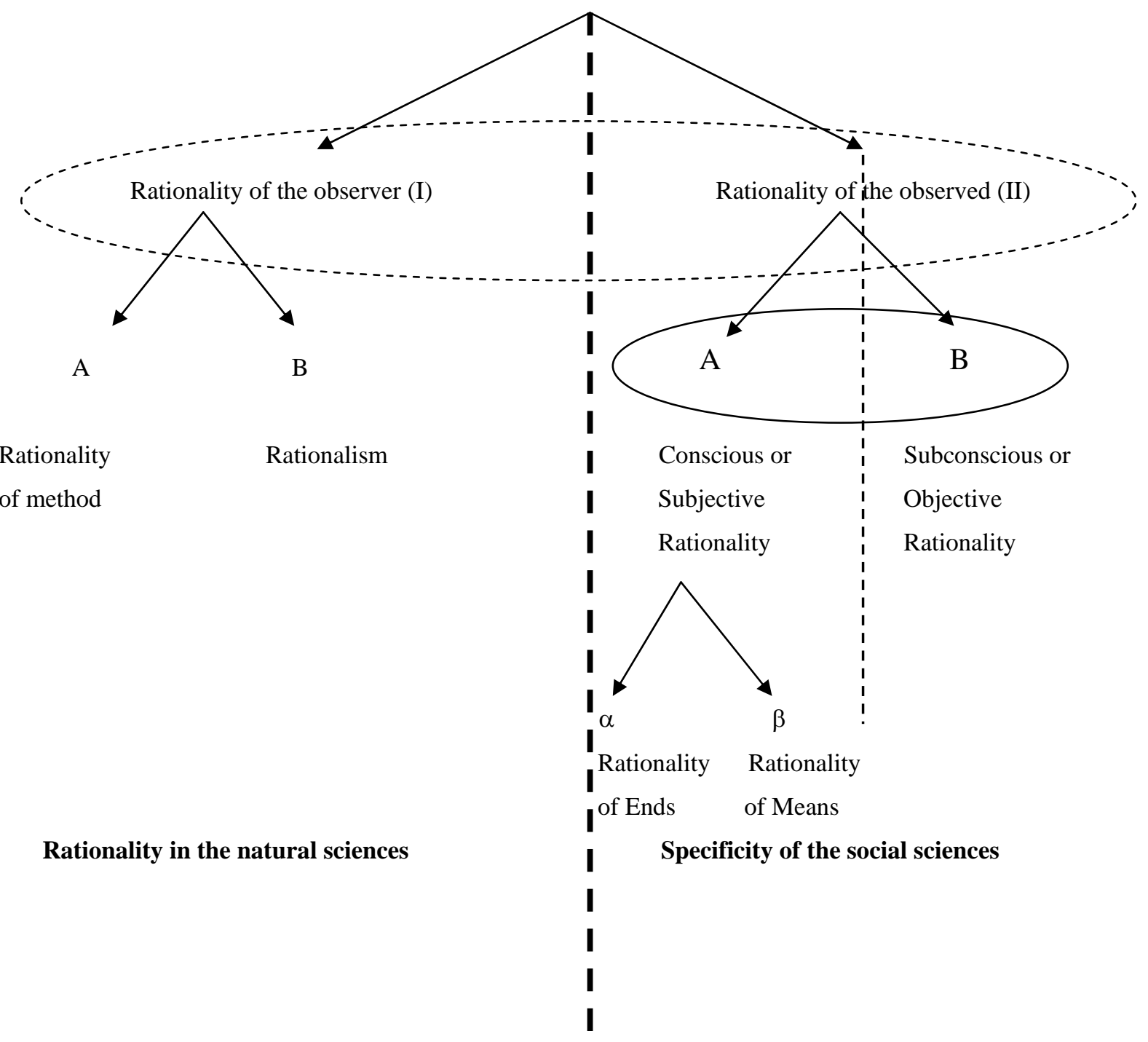

Rationality in the social sciences

Figure 1. Rational schemata or models

2. The nature and the role of social entities and Schumpeter's conception of rationality

As we have emphasized in the previous section, Schumpeter raises the issue of conflicting ends as an illustration of methodological problems associated with the notion of rationality in the social sciences. Furthermore, he also warns the reader against the use of flawed schemata of rationality based on a unique identified end, indicating that in many cases, 
actual behavior fails to confirm such rational schemata, not because individuals behave in an irrational manner, but because they often pursue several and often conflicting ends that have not been identified and prioritized correctly by the social scientist. As we will develop in this section, there is a connection between the problem of conflicting ends and Schumpeter's contribution to economic sociology, in particular, his analysis of social classes as social entities. This connection favors an institutionalist interpretation of Schumpeter's theory of economic evolution, in which conflicts between self-interest and class-interest play an important role.

In his 1940 paper, Schumpeter suggests that the problem of conflicting ends may originate in the divergence in terms of motivations between individual rationality (in the sense of self-interest) and 'collective rationality'19 (in the sense of class-interest). This is one of the main reasons why, according to Schumpeter, the observer needs to understand individuals' ends when he wants to set up logically constructed theories in the social sciences. More precisely, Schumpeter argues that the analyst or observer has to get a comprehension of individuals' ends because those ends which determine the means used to satisfy them impact on the result of individual and collective action, even if there is some irreducible indeterminacy in this result. From a different perspective, the possibility of conflicting ends permits to conceive not only the fact that non-economic ends can be important for the cohesion of social classes but also that some non-commonly shared economic ends can be followed by individuals. As we will develop below, innovations are possible only because entrepreneurs display a kind of behavior that differs from the usual maximizing (or even satisfying) economic behavior.

This conception of individual's behavior is, of course, in line with the Austrian 'subjectivist' tradition, but, more importantly, it is consistent with Schumpeter's idea that entrepreneurs, even though they are perfectly rational, follow some non-commonly shared specific economic ends. In this way, entrepreneurs are conceived as rational but, just because they do not follow merely economic ends, they do introduce disequilibrium into the stationary circular flow, thus permitting qualitative change to ensue. In other terms, the idea of noncommonly shared ends permits to put together the propositions that a stationary economic equilibrium is possible and that this equilibrium can be destabilized by some rational agents. As Schumpeter stresses, this conception is not based on psychological arguments. It is more relevant to say that it is due to his conception of individual rationality, which is strongly connected to the role of economic sociology in his general method. 
As is well known, Schumpeter's method is clearly defined in Chapter 2 of his History of Economic Analysis (1954), where he distinguishes the three 'techniques' - history, statistics and (economic) theory - that together constitute 'economic analysis'. In addition to these three techniques, there is economic sociology which constitutes a fully-fledged component of his methodology. The arguments in support of Schumpeter's claim for the introduction of a supplementary technique in the toolbox of economists may be summarized as follows.

On the one hand, he argues that the institution of property and freedom of contract or the introduction of any kind of government regulation are not only a concern of economic history but they constitute social facts that shape the society and thus make economic history a kind or generality, a type or a model. From this perspective, economic sociology can be described, in accordance with Schmoller's definition as a 'theory of generalizing history' or, as Shionoya puts it nicely, as a "bridge between history and theory" or as a "compromise between the generality meant by theory and the individuality meant by history” (Shionoya 1991; Shionoya 1997, 200).

On the other hand, Schumpeter emphasizes the fact that economic sociology provides a theory of economic behavior conceived as embedded and interacting with the institutional setting of the whole society and not assumed as a datum inherited from history. The following quotation taken from Schumpeter's History of Economic Analysis, reinforces the argument by locating the demarcation line between theory and economic sociology precisely at the level of the assumptions concerning behavior:

“ (...) economic analysis deals with the questions how people behave at any time and what the economic effects are they produce by so behaving; economic sociology deals with the question how they came to behave as they do. If we define human behaviour widely enough so that it includes not only actions and motives and propensities but also the social institutions that are relevant to economic behavior such as government, property inheritance, contract, and so on, that phrase really tells us what we need. ” (Schumpeter 1954: 47-8, underlined by us)

Therefore, economic sociology is valuable and deserves special focus because it permits to deal with the institutional background underlying economic behavior. To put it differently, economic sociology permits to endogenize a factor, namely economic behavior, which is 
usually taken as exogenous by economic analysis. Such a procedure also permits to derive heterogeneous norms of behavior, in contrast to the uniform and universal norm of behavior, i.e. the hedonistic (and static) norm of behavior taken for granted by Walrasian economic analysis. This argument can also be extended in order to deal with Schumpeter's conception of rationality. Taking into account economic sociology indeed permits a better understanding of Schumpeter's multi-level methodological perspective (in particular, the distinction 'rationality of the observer' vs. 'rationality of the observed') concerning the problem of rationality in economics. More generally, the introduction of economic sociology into Schumpeter's methodological framework permits to extend the range of application of rational models as compared to pure economic theory.

Finally, and more generally, economic sociology can be interpreted as a bridge between statics and dynamics, or as means to unify Schumpeter's analytical framework, by qualifying the usual argument of the logical inconsistency between the routine-based static circular flow and the case of development, supposedly arising endogenously from the circular flow. If economic sociology can be considered as secondary for economists whom interest is focused on the working of stationary economic states, it becomes however a central issue for dealing with economic dynamics, as Schumpeter defines it, i.e., "such changes in economic life as are not forced upon it from without but arise by its own initiative, from within.” (Schumpeter 1934, 63). Under those circumstances, economic sociology cannot be considered as non economical, and thus must also to be distinguished from simple sociology. Moreover, since Schumpeter excludes from the definition of economic development such changes in data or in economic conditions, to which the economy continuously adapts (ibid), economic sociology provides the tool for dealing with the social structure of an economic system. More precisely, for Schumpeter, economic sociology or social institutions are more than a complement to economic analysis. They rather constitute a logical priority to it. In other terms, for Schumpeter, it is not possible to deal with economic change without considering complementary and necessary previous institutional change ${ }^{20}$ (see Figure 2). 
Increasing degree of abstraction

\begin{tabular}{|c|c|c|c|}
\hline $\begin{array}{l}\text { Economic } \\
\text { history }\end{array}$ & $\begin{array}{l}\text { Economic } \\
\text { sociology }\end{array}$ & $\begin{array}{l}\text { Economic } \\
\text { theory }\end{array}$ & \\
\hline $\begin{array}{l}\text { Multiplicity of } \\
\text { behavioral patterns } \\
\text { according to the } \\
\text { historical and cultural } \\
\text { contexts }\end{array}$ & $\begin{array}{l}\text { Some norms of behavior or } \\
\text { regularities } \\
\text { Adaptive / Innovative } \\
\text { behavior embedded and } \\
\text { interacting with the } \\
\text { institutional setting. }\end{array}$ & $\begin{array}{l}\text { A uniform and universal } \\
\text { norm of behavior: } \\
\text { Hedonistic behavior } \\
\end{array}$ & Behavior \\
\hline \multirow[t]{2}{*}{$\begin{array}{l}\text { Infinite variety } \\
\text { of cognitive ends }\end{array}$} & $\begin{array}{l}\text { Conflicting ends } \\
\text { Class interest / self-interest }\end{array}$ & Single end & Rationality \\
\hline & $\begin{array}{l}\text { Institutional and economic } \\
\text { change }\end{array}$ & Statics & \\
\hline
\end{tabular}

Figure 2. The place of economic sociology in Schumpeter's method

To put in a nutshell, what we want to emphasize here is the fact that individual behavior is determined by a bundle of individual as well as collective ends - as captured, essentially, by the distinction between self-interest and class-interest - that may conflict with each other, and may explain the heterogeneity of observed behaviors. Moreover, individual behaviors are contextualized insofar as individuals have to realize some functions that are socially defined. We will see below that their capacities to perform those functions make them evolving inside the society, improving or worsening their social positions accordingly. It is their very aptitude to perform those social functions that permit them to increase their position inside the social structure. The effectiveness of their actions is also conditioned by the social environment: in some cases there can be some resistance to novelty due to established social values, behavioral routines, etc. In this case, leadership is the main aptitude they have to possess in order to break with old habits or tradition.

But before analyzing Schumpeter's approach of the relationships between individual behaviors and the social structure, we need to make a detour via his analysis of the nature, function and evolution of social classes. 
According to Schumpeter, social classes can be conceived either as social organisms that act as such, i.e., social entities per se, or as the invention of researchers. The problem is that those two conceptions of social classes are often confused. More precisely, in his 1927 Essay on social classes, Schumpeter identifies four problems that arise when "sociological scientists” try to define social classes: the nature of classes (and their functions), class cohesion, class formation (that explains why the social whole is not homogenous) and "the concrete causes and conditions of an individually determined, historically given class structure” (Schumpeter (1991) [1927], 233). This last problem is important because it reinforces the idea that classes are historically dependent entities. In sum, for Schumpeter, groups or social classes are not in general to be explained by reference to a particular purpose. Mostly, sociological location and history are necessary to understand their nature and behavior. Finally, Schumpeter considers that, although there is no such thing as classless society, it is nevertheless possible to identify principles that explain the formation, nature and basic laws of social classes.

As far as the relationships between individual rationality and social entities are concerned, Schumpeter first stresses that "the class membership of an individual is a primary fact, originally quite independent of his will”, although “(...) he does not always confirm that allegiance by his conduct.” (ibid, 236).

In the first part of this quotation, Schumpeter specifies the unit of selection that underlies his conception of social classes: family is conceived as the definite unit of selection (see Figure 3). Individuals belong to families and family is then the primary and relevant level of analysis of the selection process ${ }^{21}$.

The second part of the quotation, however, stresses the fact that individuals are within a given economic and social context the active units of evolution (see Figure 3$)^{22}$. More precisely, only individuals permit the modifications of 1) the position of individuals' families inside a class, 2) the families' capability to cross the boundaries of classes and 3) finally the rise and fall of classes. In fact, “it is always 'behavior' and 'aptitude' that explain shifts in the relative positions which originally existed.” (ibid, 246). The shifts that characterize the evolution of class structure need to be linked with the importance of the "method of striking out along unconventional paths" which is, with chance and success "along wonted and ordained lines” the most important element that explains rising higher classes ${ }^{23}$. This idea strengthens the fact that individuals possess all the same basic characteristics ${ }^{24}$ that make them adaptable to specific historical contexts. Capitalism is not creating entirely new individuals not existing before inside other classes but permits individuals to manifest 
differently their aptitudes: "[b]ecause of the limited opportunities open to working-class families, this is virtually the only method by which they can make the great leap out of their class.” (ibid). In other words, class composition is constantly changing: it "resembles a hotel or an omnibus, always full, but always of different people.” (ibid, 248).

If individuals are, due to their personal aptitudes, able to change the relative position of their families inside a given social and economic context, the principle of selection that makes them successful in their enterprise is defined by the extent to which they have the capacities to perform some specific social functions. Accordingly, the functional adequacy of behaviors is the relevant principle of selection (see Figure 3). This functional vision of the class structure is perfectly illustrated by the following quotation:

"Just as the manorial system corresponds to the type of the knightly warrior-politician and warrior-administrator, so the system of large landed estates corresponds to the type of the aristocratic businessman." (ibid, 268, italics in the original)

Consequently "the social importance of class members varies with (...) two basic elements - the importance of the class function and the degree of success in carrying out that function.” (ibid, 272). However, the adequacy between class structure and social functions first, is not an automatic and direct relation; second, is determined by an economic logic and third, is a long and slow process.

First, the process of evolution of classes and class structure is not straightforward in the sense that there exists no direct relationship between the existence of a class and its actual function. In particular, classes can survive even if the conditions that explain their existence have disappeared: "[c]lasses, once they have come into being, harden in their mold and perpetuate themselves, even when the social conditions that created them have disappeared.” (ibid, 237). This social inertia corresponds to the existence of a kind of 'hysteresis effect' (the cause has disappeared but the effect remains). Moreover, the processes of translation of social functions into institutional rules are heterogeneous and have different lags depending of the kinds of rules concerned: "the 'superstructure' of law, custom, and so forth is always the last to change, always lags behind changes in the actual life situation.” (ibid, 262). Finally, the members of a declining class can use some stratagems in order to slow down the decline of their social position insofar as the "survival of some conspicuous externals serve to slow down the full effect of the internal [and necessary] change.” (ibid, 266). To sum up, "there is an understandable tendency to continue the old functions in form rather than in substance.” 
(ibid, 264). Success partly explains this inertia. More precisely, "success, once achieved, exerts a continuing effect, without further accomplishment, for two reasons: first of all, the prestige it engenders assumes a life of its own. It does not necessarily vanish when its basis fades away - nor, for that matter, does its basis readily disappear. This is the very heart and soul of the independent organic existence of "class". In the second place, in the vast majority of cases, success brings in its wake important functional positions and other powers over material resources. The position of the physical individual becomes entrenched, and with it that of the family.” (ibid, 278-9).

Second, the 'ultimate causes' of the evolution of social functions are economic ones, even if sometimes they do not appear as conspicuous or immediate: “(...) such causes, on their part, can always be reduced to those basic elements [the importance of the class function and the degree of success in carrying out that function], just as, according to the economic interpretation of history, the flow of social events is always, ultimately shaped by the inner logic of the economic machine, though very often this influence is anything but direct." (ibid, 272). Social functions are then in their very definition and evolution determined by economic factors $^{25}$. Those economic ultimate causes are however not directly leading the actual evolution of class structure as emphasized in the previous quotation. Consequently, there is a sort of disconnection between the fundamental economic causes and the apparent evolution of class structure. This feature is also emphasized, as already pointed out, in Schumpeter's Theory of Economic Development, where the author refers on the one hand, to "the fundamental dependence of the economic aspect of things on everything else", and on the other hand, states that, as a consequence, "it is not possible to explain economic change by previous economic conditions alone" so that "we can state that the economic world is relatively autonomous because it takes up such a great part of a nation's life, and forms or conditions a great part of the remainder" (Schumpeter 1934, 58)

Third, the 'functional' evolution is not a fast and 'punctuated' equilibrium phenomenon ${ }^{26}$. In fact, even if some accidents such as revolutions or wars can accelerate the social evolutionary process ${ }^{27}$, the quick changes are mainly due to the failure of the incumbent upper classes to remain at their positions and then to perform their (or some new) social functions: "[f]rom the viewpoint of class history and class theory, we are concerned, first, with the fact that class functions and their relative social necessity change only slowly.” (ibid, 276).

What seems important to remember at this stage in order to grasp the main features of social evolution in Schumpeter is that individuals are the units of the evolution of the structure 
of social classes. Their aptitude to satisfy necessary social functions makes their family, which is the unit of selection, evolving inside the social class structure. However, the evolution of the social class structure usually lags behind the evolution of the social functions, due to both inertia phenomena (comparable to hysteresis effects) and resistance from families to the evolution of their social status. Individuals' behaviors that are the mainspring of social evolution are nevertheless indirectly subject to the evolution of the position of the family and the social class they belong to, the function of which, as we have emphasized is ultimately driven by economic forces. Finally, individuals' aptitudes and in fine, individuals' ends, which characterize their rationality, are the basic elements that explain the efficiency of their actions. If differences in individuals' aptitudes, and in particular, the aptitude for leadership explains the evolution of the family position in a given social class structure and of the relative position of the social classes themselves, they amount, in the final resort, to differences in the individual's bundles of ends that motivate the acquisition of aptitudes (even if some aptitudes are partially given or socially inherited). In fact, for Schumpeter, individuals' aptitudes are embedded in an ethically homogeneous environment and are “probably distributed according to a normal curve.” (ibid, 276). As Schumpeter emphasizes: "our present purpose is served well enough by the fact, scarcely disputed, that individual differences do exist and that individual aptitudes do not fall into sharply marked categories, separated by empty space, but shade by imperceptible nuances from high to low.” (ibid, 277). Moreover, differences in aptitudes, such as the aptitude for leadership for instance, are defined as "special function[s], always clearly discernible in the actions of the individual and within a social whole. [They] emerge only with respect to ever new individual and social situations and would never exist if individual and national life always ran its course in the same way and by the same routine.” (ibid. 278). It is therefore the abilities of some individuals to escape from routinized motivations that explain the emergence of new aptitudes and, finally, of new behaviors. As Schumpeter emphasizes in Capitalism, Socialism and Democracy, routines are part of the underlying institutional setting "which compel individuals and groups to behave in certain ways whatever they may wish to do - not indeed by destroying their freedom of choice but by shaping the choosing mentalities and by narrowing the list of possibilities from which to choose. (Schumpeter 1950, 129-30).

This feature is perfectly in line with the idea that individuals' rationality is related to a trade-off between possible conflicting ends, which results in a given behavior (which conveys the relation between means and ends). Furthermore, since the composition of the bundle of ends (in particular, the relative weight of individual and social motives) evolve through time, 
some ends are likely to emerge, while others may disappear, depending on the ability of individuals, i.e., their aptitudes, to perform some necessary social functions in a given economic environment. Moreover, as we shall now develop more deeply, the performance of individual actors also depends on the institutional and social context in which they are embedded. In particular, institutional change, and therefore, economic change, can be triggered if some agents have not only the aptitude, but also the energy to go beyond establish collective routines. In such a case, the element of novelty which is introduced in the society is likely to be diffused and to exert lasting effects on individuals' behaviors in the future.

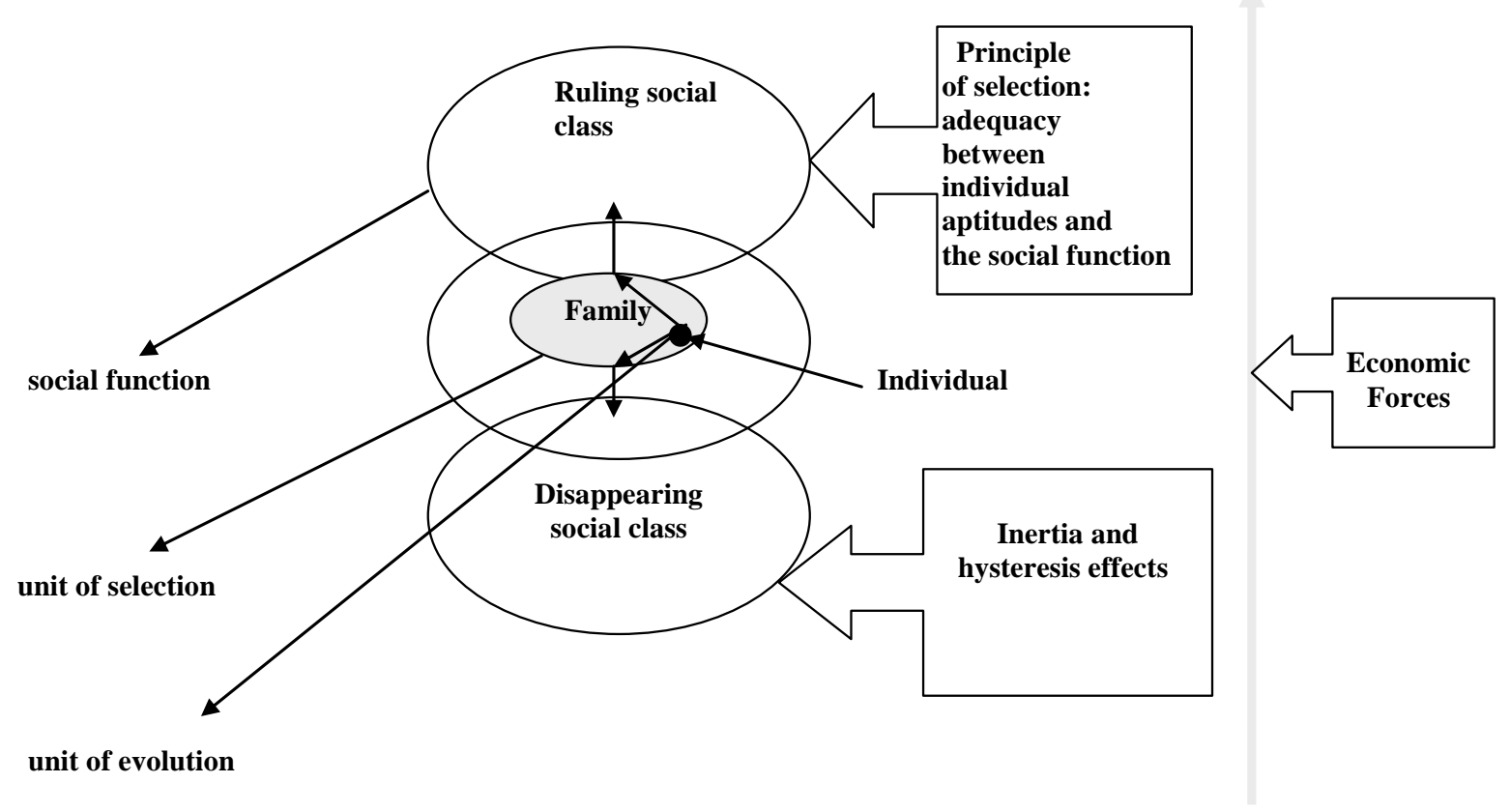

Figure 3. Evolution of the social class structure

3. The relationships between individual rationality and collective entities and Schumpeter's conception of institutional and economic change.

In this section, we argue that Schumpeter's theory of institutional and economic change needs to be analyzed in relation to his conception of the relationships between individual rationality and social class structure dynamics. 
According to Schumpeter, there is a correspondence, sometimes weak, between the economic and social functions and individuals' conflicting ends. This correspondence is effective as soon as individuals reveal some aptitudes to perform their economic and social functions. It is the reason why human motives are never strictly individual and that their effective behaviors are only the symptom of the existence of their class membership. Rather, they are always embedded in a social and historical context under which they have emerged. This characteristic is symptomatic of Schumpeter methodological approach. As Donzelli (1983: 639) reminds us, as early as in 1908 in his doctorate dissertation, Schumpeter devoted an entire chapter to a detailed discussion on methodological individualism vs. methodological holism, aiming not at establishing the superiority of either approach, but rather, at specifying their respective arenas of application ${ }^{28}$. Moreover, according to Agassi the three respective characteristics $^{29}$ of holism and individualism contradict if and only if a fourth proposition is added: "If 'wholes' exist then they have distinct aims and interests of their own.” (Agassi 1975, 147). Because Schumpeter does not accept such a proposition (which, Agassi shows, is easily avoidable) it follows that his holism and individualism do not contradict.

In his 1927 essay on Social Classes, as already emphasized, Schumpeter attempts to evaluate the impact of social classes on individual motives and behaviors and assesses that social forces do have some autonomy vis-à-vis individual motives or ends. This feature does not imply, however, that individuals have no leeway in their actions. We indeed have shown that, in Schumpeter, the construction process of social class rests on individuals' aptitudes and their adequacy with the social function they have to perform in a given society.

On the other hand, Schumpeter uses the notion of rationality for individuals but assumes the existence of classes as real and effective entities. As we wrote above, this last aspect is perfectly developed in Schumpeter ([1991] 1927) and the idea that classes or collective entities (families) can 'act' as such is fundamental ${ }^{30}$. This aspect is also to be compared with Wieser's approach to the evolution of institutions (Festré, 2006). Wieser indeed emphasizes the idea that collective entities ('masses' and 'power strata' in Wieser (1926)) do exist. This feature allows both Wieser and Schumpeter to provide an analysis of the evolution of institutions and not only of their emergence inasmuch as these two levels (the individual and the collective one) do interact.

Such an interpretation of Schumpeter also challenges Perroux, who criticizes Schumpeter, in his well-known introduction to the French translation of the Theory of Economic Development, for having provided only a theory of emergence and not a theory of evolution of institutions. This is perfectly right insofar as we suppose that Schumpeter's methodology is 
only an individualistic one. If however one considers that his methodology is both individualistic and holistic, then the emergence and the evolution of institutions and, more generally, of the evolution of the whole economy can be reconciled on the basis of an institutionalist interpretation of Schumpeter's conception of economic development (Festré and Nasica, 2006). Institutions and institutional change indeed permit some behaviors to emerge, so that institutions can partly be seen as the crystallization of individuals' behaviors. For instance, the emergence of bankers permitting the creation and diffusion of credit (as an economic institution) in the economic system supports the existence of entrepreneurs as innovators. The banking system must already exist as a matter of logical priority for capitalist forms of entrepreneurship to develop. But the banking system is not only a specific form of social organization; it also supports the diffusion of new behavioural rules, which are more adapted to industrial organization.

Accordingly, there is a phenomenon of composition of individuals' behaviors following specific (understandable) ends and connecting means with these ends, which permits the emergence of collective local ends that appear as constraints and can possibly enter in conflict with the ends of individuals belonging to those collective entities. Such an explanation is a possible way for creating compatibility between the existence of both individualism and holism in Schumpeter's works. It also paves the way for his conception of economic development based on an institutionalist approach of evolution.

In sum, economic as well as social evolution is co-determined by individual as well as collective forces. Individuals’ behaviors are not entirely determined by collective and social constraints. They can give up routines and socially anchored behaviors. This possibility lies in the Schumpeterian conception of individuals' motives and then of conflicting ends. Nevertheless, those 'out of conventions' behaviors need to be socially approved of in terms of the functions they can perform. What seems to be crucial for Schumpeter is that novelty, economic and institutional change cannot be grasped on purely individualistic terms. Moreover, this process involves a specific conception of individual behavior and rationality.

On one hand, some kind of energy as well as leadership are required, which explain why Schumpeter privileges the captain of industry or the promoter form of entrepreneurship in his theoretical construction of economic development. The notion of energy is indeed connected to Schumpeter's analysis of leadership defined as a "special function”, which is a permanent feature of human societies and aims at taking the predominant decisions for the future of society (Schumpeter 1927 [1991], 278. As is well known, the reference to social leadership is 
quite widespread within the Austrian literature. Max Weber also introduced the concept of the 'charismatic leader', which, though defined differently from Schumpeter's leadership, is also associated with social change and the introduction of new behavioral rules and social norms. Wieser also provided an analysis of leadership conceived as a permanent feature of civilization, ruled by the law of small numbers and whose function is to permit economic and social progress.

The reference to energy and leadership as decisive factors of evolution are frequent in Schumpeter's writings. In his essay entitled The Sociology of Imperalisms, Schumpeter refers to the "instinctive urge to domination" (Schumpeter 1951 [1919], p. 15) or to "activity urges springing from capacities and inclinations that had once been crucial to survival, though they had now outlived their usefulness” (ibid. p. 44). These 'urges' (or Trieb, ibid. p. 83) are defined by Schumpeter as human inclinations that have more to do with 'instinct' than with reason (ibid. p 83-4). In warlike societies, those kind of urges are devoted to fighting , whereas in capitalist societies, excess energy is channeled into the introduction of innovations, such as new products, new productive techniques, or new corporate organizational forms.

In his 1908 doctorate dissertation (Habilitations-Schrift) entitled Das Wesen und der Hauptinhalt der theoretischen Nationalökonomie as well as in the first German edition of his TED, Schumpeter contrasts the energetic form of egoism to the hedonistic one (Schumpeter 1908: 86-87; Schumpeter 1912). ‘Hedonistic egoism’ describes Walrasian rational behavior whereas the notion of 'energetic egoism' is confined to an active and 'volontarist' behavior based on a different kind of rationality (see Santanelli and Pesciarelli 1990 p. 684-7 and Arena 1992 pp. 133-5). This distinction permits, in particular, as we shall analyze, to contrast the purest form of entrepreneurship from other producers who essentially follow routines of behavior.

This distinction must also be put in perspective with Schumpeter's 1940 article on rationality. As we have shown, in this paper, Schumpeter reasserts his reservations about the use of strict individualism within social sciences, which assumes: "that the individuals under research - sometimes even the 'people' as such - are themselves actuated by clearly perceived motives, and regulate their behavior with conscious rationality working in the full daylight of the egos (subjective rationality).” By relying on such a procedure, however, "analysts, especially those of bygone generations, have almost overrated the actual range of consciously rational action.” (Schumpeter 1991 [1940], 326) 
On the other hand, there must be something more for novelty to operate. To understand Schumpeter's attempt to deal with this difficult issue requires us to look carefully at his early writings dedicated to economic sociology as well as to account, again, for his dual, both individualistic and holistic, methodology. Contrary to what is usually maintained in the literature (see for instance Perroux, op. cit.), we think that Schumpeter not only provided an explanation of the emergence of change but also offered some very insightful principles of how institutions and behavior may evolve. This interpretation is reinforced if we take Schumpeter's way of dealing with rationality seriously, and in particular, the idea that individuals' ends may result from conflicts between self-interest and class-interest. Those ends, which are distinct from instincts, impact on behaviors, which are then both individually and collectively determined. This conception of individuals' behavior, as resulting from both self and social determination, permits first to avoid a purely instinct-based approach and second to justify a methodology that combines the individualistic approach with the holistic one. However, if aptitude and conscious behavior explain the heterogeneity of individual behaviors and the possibility of conflicting ends between self-interest and class-interest, unconscious or instinctive capacities, as emphasized above, also play a role in triggering changes in routines or behavior. For Schumpeter, the unconscious urges also involve creativity and entail permanent changes as well as self-reinforcing mechanisms in the sphere in which they appear. Referring to "warrior nations" (Schumpeter 1951 [1919], 49), Schumpeter argues that "the explanation lies, instead, in the vital needs of situations that molded peoples and classes into warriors - if they wanted to avoid extinction - and in the fact that psychological dispositions and social structures acquired in the past in such situations, once firmly established, tend to maintain themselves and to continue in effect long after they have lost their meaning and their life-preserving function.” (Schumpeter 1951 [1919], 83-4). Schumpeter adds that history shows why and how these civilizations survived. The survival of those civilizations indeed implies the crystallization of all "popular forces" that characterize this people, included "those in the ideological sphere" in order to constitute "a war machine that, once in motion, continues so long as there is steam behind it and it does not run up against a stone wall.” (Schumpeter 1951 [1919], 49).

But what explains the longevity of such civilizations is more the phenomenon of leadership than passive adaptation. In a footnote, Schumpeter writes: "this is no mere analogy [i.e. the analogy to a war machine] of the kind rightly held in contempt. We are dealing with 
the facts that every purposive organization by its mere existence adapts its members to its purpose.” (Schumpeter 1951 [1919], 49 fn.). Shionoya summarizes the role played by creative activity and novelty in Schumpeter, emphasizing that it inevitably entails some indeterminacy and some path-dependency. Moreover, creative activity is also related to the phenomenon of leadership. As emphasized by Shionoya:

\begin{abstract}
"In the first place, creative activity cannot be predicted by applying the ordinary rules of inference from the pre-existing facts. It is so unique that the mechanism of the modus operandi must be examined on a case-by-case basis. Second, creative activity shapes the whole course of subsequent events and their long-term outcome, causes discontinuity from preceding situations. Third, creative activity is an enigma of human beings and has something to do with the distribution of talent and therefore with the phenomenon of leadership.” (Shionoya 1997, 175).
\end{abstract}

Schumpeter's claim for the use of economic sociology within his overall methodological approach reinforces his reluctance to a pure individualist approach to social sciences, in particular, if it is associated with a universally alleged objective rational behavior $^{31}$. The recourse to economic sociology indeed permits to assess a key role for leadership as a recurrent characteristic for institutional and economic change to occur. As we have emphasized, institutional change involves the emergence of new behavioral and social norms. Leadership is indeed associated with the motivation of breaking up with routines that is rendered possible by the excess of energy that characterizes them. But their success does not only depend on their intrinsic characteristics, but also on their social leadership, i.e., on their ability to make novelty being accepted by the community of followers or imitators. This process of diffusion is based on self-organization and self-reinforcement mechanisms, but also on social imitation, which takes place on a multi-level - family, intra- and inter- class basis. Finally, we have illustrated that economic sociology can be seen as a conceptual bridge between history and economic theory, insofar as it permits to discern amongst the varied origins and institutional settings that shape the social world similar patterns of behaviors that characterize normative phenomena, such as leadership. From this perspective, and as will be shown in the following, entrepreneurship can only be considered as a derived form of leadership associated with peculiar behavioral and rationality features. 
The relationships between individual rationality and class structure as well as the key role played by economic sociology in Schumpeter can be exemplified by his conception of entrepreneurship. In a 1928 paper entitled Unternehmer (Entrepreneur), Schumpeter provides a typology of individual-level forms of entrepreneurship. In this article, he distinguishes between four "types of modern entrepreneurship” (Schumpeter, 1928: 483-5; translation by Becker and Knudsen, 2003: 251-4): the factory owner and merchant; the modern captain of industry; the manager who actually carries out the entrepreneurial function and the 'founder' (promoter)

Schumpeter distinguishes those four types from a multi-criteria perspective according to a) the selection process; b) the functions (or managerial roles) fulfilled; c) the social position; d) the relationship between entrepreneurial position and capital; e) the values (both individual and social), i.e., in other terms, following Schumpeter's terminology in his 1940 paper on rationality, the result and expression of conflicting ends; f) the motivation; g) the competence (aptitude) in particular business matters ${ }^{32}$. In what follows, we will focus in particular on four of those criteria, namely, the motivation, the aptitudes, the function and the social position of the different types of entrepreneurs, as summarized in Figure 4. Our main point is to show that conflicting ends generate motivations that produce aptitudes.

\begin{tabular}{|l|l|l|l|l|}
\hline Criteria & $\begin{array}{l}\text { Factory owner and } \\
\text { merchant }\end{array}$ & Manager & $\begin{array}{l}\text { Modern captain of } \\
\text { industry }\end{array}$ & $\begin{array}{l}\text { Founder } \\
\text { promoter }\end{array}$ \\
\hline Motivation & $\begin{array}{l}\text { Present and future care of } \\
\text { the family } \\
\text { Non-rational love for the } \\
\text { firm } \\
\text { Social feeling oriented } \\
\text { towards voluntary care }\end{array}$ & $\begin{array}{l}\text { Sufficient income } \\
\text { Good professional } \\
\text { performance } \\
\text { Applause of the } \\
\text { colleague and the } \\
\text { public } \\
\text { Personal reputation }\end{array}$ & $\begin{array}{l}\text { Power } \\
\text { Will to win } \\
\text { Performance } \\
\text { Urge to action }\end{array}$ & $\begin{array}{l}\text { Seeking and } \\
\text { carrying out of new } \\
\text { activities } \\
\text { Intrinsic motivation } \\
\text { (gratification from } \\
\text { what he has done) }\end{array}$ \\
\hline Aptitude & $\begin{array}{l}\text { Bourgeois properness } \\
\text { Business acumen } \\
\text { Family spirit }\end{array}$ & $\begin{array}{l}\text { Recognition of } \\
\text { others } \\
\text { Auttainment of } \\
\text { Conseracy }\end{array}$ & Solving problems & $\begin{array}{l}\text { Starting new } \\
\text { businesses }\end{array}$ \\
\hline Function & $\begin{array}{l}\text { Unite many heterogeneous } \\
\text { functions } \\
\text { (planning, the arrangement } \\
\text { of factors of production, the } \\
\text { fixation of prices, the } \\
\text { implementation of } \\
\text { production...) }\end{array}$ & $\begin{array}{l}\text { Middleman- } \\
\text { functions between } \\
\text { the different } \\
\text { stakeholders }\end{array}$ & $\begin{array}{l}\text { Coordinate the } \\
\text { general direction of } \\
\text { the business policy } \\
\text { of his companies } \\
\text { Decide in } \\
\text { dangerous } \\
\text { situations } \\
\text { Creates novelty }\end{array}$ & $\begin{array}{l}\text { Focused on the } \\
\text { entrepreneurial } \\
\text { function (+ } \\
\text { functions of } \\
\text { secondary } \\
\text { importance: legal } \\
\text { and financial } \\
\text { matters. }\end{array}$ \\
\hline $\begin{array}{l}\text { Social } \\
\text { position }\end{array}$ & $\begin{array}{l}\text { A definite social position } \\
\text { similar to the one of } \\
\text { capitalists }\end{array}$ & $\begin{array}{l}\text { No particular social } \\
\text { position (division } \\
\text { of ownership and } \\
\text { control) }\end{array}$ & $\begin{array}{l}\text { Ability to } \\
\text { command and } \\
\text { dominate } \\
\text { (leadership) }\end{array}$ & $\begin{array}{l}\text { No social reference } \\
\text { point } \\
\text { Often low social } \\
\text { and moral status }\end{array}$ \\
\hline
\end{tabular}


Regarding the aptitude criterion, the different types of entrepreneurs are described by Schumpeter as follows: the factory owner and merchant is characterized by bourgeois properness, business acumen, family spirit, autocracy and conservatism; the manager is motivated by recognition of others (reputation) and attainment of moral values; the promoter is competent in starting new businesses and not so much in running them once started; the captain of industry is interested in solving problems, more than in business and, against his will, he is the pioneer of the planned economy.

The analysis of the motivation criterion permits to illustrate the problem of conflict between self-interest and class-interest from the perspective of Schumpeter's conception of rationality and to stress the idea that conflicting ends produce motivation that results in aptitude. In this respect, the factory owner's attention is turned towards the present and future care of his family and towards a 'non-rational' love for the firm and his social feeling is oriented towards acts of voluntary care. The manager's motivation is described as an intermediate form of selfinterest: sufficient income and orientation towards the idea of good professional performance, applause of the colleagues and the public, as well as personal reputation. The promoter's motivation is oriented towards the seeking and carrying out of new activities, i.e. intrinsic motivation and gratification from doing that. Finally, the captain of industry is described as someone, who does not only follow his own interests or his family interests, who is not simply oriented towards profit as such, but also towards power, performance, the will to win, and the urge to action.

From the viewpoint of their functions, the four kinds of entrepreneurs are associated with the following characteristics. The factory owner and merchant appears to unite many heterogeneous functions (planning, the arrangement of factors of production, the fixation of prices, the implementation of production); the manager performs many functions, amongst which middleman-functions that sometimes lead to new combinations; the promoter is completely focused on the entrepreneurial function even if he also regularly carries out legal work and tends to matters of technical finance; the modern captain of industry is the purest type of entrepreneur since he does not fulfill accessory functions (as the other types of entrepreneurs do) but coordinates the general direction of the business policy of his companies, creates novelty, and decides in dangerous situations. It is therefore no surprise that the modern captain of industry is the type of entrepreneurship designed for economic change. 
If we finally turn to the social position criterion, one can note the crucial role of leadership for economic change to occur, i.e., the ability to command and dominate, which all the types of entrepreneurs, except the captain of industry, are deprived of. This ability is partly individual and partly social, in compliance to our previous discussion on individual rationality and social classes. Moreover, it is not limited to the problem of modern entrepreneurship. It also characterizes other historical phenomena, such as imperialism (see Schumpeter 1951 [1919]).

\section{Conclusion}

Schumpeter's writings are marked by his constant interest in individual behaviors and rationality. Moreover, in his early writings on economic sociology (1951 [1919] and [1927] he constantly stressed the fact that individuals have to perform "necessary social functions". His conception of social classes is based on the idea that class structure emerges and evolves because individuals, motivated by conflicting ends, perform differently, according to their specific aptitudes and the social functions corresponding to the class their families belong to. This correspondence is however not a perfect and automatic one: first, because it is subject to lags, due both to historical inertia and to the existence of delays in the speed of change of the different institutional rules; second, it is relative to the behavior of individuals that are not always fulfilling routines, i.e., 'conventional paths', but innovate in terms of behavior instead.

This very specific conception of institutional change, which is both individualistic and holistic, explains why Schumpeter is so difficult to rank among the economists of the Austrian tradition, even though he really contributed to the development of some key tenets of this School. What makes also Schumpeter's conception of economic and social change very modern is the fact that institutions are conceived as a multi-level set of rules, each subset having its own logic in terms of functions as well as in terms of evolution. From the perspective of recent economic literature devoted to the relationships between institutional framework and economic development, Schumpeter's works definitely give us fruitful insights ${ }^{33}$. 


\footnotetext{
${ }^{1}$ As noted by Swedberg (2006), Schumpeter's decision to have a seminar on rationality at Harvard in 1939-40 was triggered in 1939 by a paper on rationality by Chester Barnard. In fact, there were about 10 meetings,
} starting in October 1939 and ending in April 1940. An attempt to put together a book from the papers that were presented at the seminar failed, partly because Parsons, who had been appointed co-editor by Schumpeter, lost interest. Parsons later confessed that he, in fact, let the project die (Swedberg 2006: 72). Schumpeter’s paper presented to the seminar entitled "The meaning of rationality on the social sciences" was many years later published by Swedberg (1991), while Parsons’ paper entitled “An approach to the analysis of the role of rationality in social action” has remained unpublished.

${ }^{2}$ This conception has to be linked with Schumpeter's instrumentalism. See Shionoya (1990) and Gonçalves Da Silva (2002) for more details on this point. It is however not our aim to deal with this aspect of Schumpeter's methodology inasmuch as it does not interfere with our objective. See also Machlup (1951) who shows that Schumpeter both stresses the arbitrariness of the theory and the need for the theory to fit the phenomena. ${ }^{3}$ Related to this matter, Schumpeter parts company with Max Weber concerning his denial of rationality to the ancient Chinese on the ground that they relied on examinations in classical literature as a remedy for shortcomings displayed in dealing with catastrophic floods (Schumpeter [1940] 1991, 325)

${ }^{4}$ We will see below that this idea is close to what Parsons and Schütz actually developed. Schumpeter red Parsons (1937) and appreciated it (see Swedberg 2006). He also has been influenced by Schütz’s works. Schütz red Parsons' book while writing a paper Hayek asked him for Economica from which he was the editor.

${ }^{5}$ He points out that "all that can be legitimately claimed for them [i.e., the ends], on the scientific plane, reduces to, first, the task of working out the consequences that action taken in order to realize any given ultimate end would have; second, the task of explaining why given people at any given time and place should feel about any given ultimate ends as they actually do.” (ibid, 318)

${ }^{6}$ The proposition 'if then' is true when the consequent is true and the precedent is false. In other words, it is possible to deduce a true property from a false one.

${ }^{7}$ Except for the cases of theories or models based on objective and quantitative relationships, such as those derived from data analysis, for instance, or founded on objective and quantitative relationships, such as data analysis, for instance (ibid 319-20). These exceptions also refer to two components (the set of theories based on logical arguments and the set of theories founded on observations) of the typology of economic theories made by Schumpeter in the second chapter of his History of Economic Analysis. 
${ }^{8}$ It is interesting to note, in passing, that on this issue, Schumpeter disagrees with Weber. As pointed out by Walter W. Powell, Schumpeter made several references in his History of Economic Analysis to Weber's ‘misleading’ and 'regrettable’ methodology (Schumpeter 1954, 777). In particular, Schumpeter took issue with a core idea of Weber's that "while we can explain the phenomena of nature, we must understand the phenomena of the mind (or of culture)" (Powell 1996, 922). At first sight, this does not seem to be in contradiction with Schumpeter. But deeper investigation shows that those parallels between Schumpeter and Weber are only surface parallels which mask profound divergence between the two authors on the issue of methodology. In particular, Schumpeter dismissed Weber's use of ideal types, unable to comprehend their utility as yardsticks (Powell 1996, 922). For a comparison between Schumpeter and Weber, see MacDonald (1965) and Hansen (1966).

On the issue of rationality in social sciences, what is important to remember, according to Schumpeter, is that it usually requires to set a norm of behavior. The fact that this norm is the result of a process of understanding does not imply however that, once it is set by the analyst, economic analysis differs substantially from other sciences. ${ }^{9}$ It is perfectly in line with the following from Schütz: "The first fundamental consequence of this shift in the point of view is that the scientist replaces the human beings he observe as actors on the social stage by puppets created by himself and manipulated by himself.” $(1943,143)$.

${ }^{10}$ It is interesting to note that this passage is perfectly in line with what Alchian (1950) and Friedman (1953) assume when they consider that producers need not consciously maximize profit and that they are able or not to calculate marginal revenue and marginal cost. It suffices to say that they need to do so if they want to survive. 11 "Social phenomena, on the contrary, we want to understand and we cannot understand them otherwise than within the scheme of human motives, human means and ends, human planning -in short- within the categories of human action.” (Schütz 1943, 146).

${ }^{12}$ This idea is expressed by Schütz as the postulate of the subjective interpretation and formulated as follows: "The scientist has to ask what type of individual mind can be constructed and what typical thoughts must be attributed to it to explain the fact in question as the result of its activity within an understandable relation.” (Schütz, 1943, 147). He stresses that this postulate complements Weber's postulate of adequacy.

${ }^{13}$ Page 330 Schumpeter explicitly writes that businessmen may be altruistic (even if based on 'egoistical' wish). This point sounds very modern if related to recent results in experimental economics.

${ }^{14}$ See note 2 in this article. 
${ }^{15}$ Schumpeter acknowledges in a footnote that the terms "subjective rationality" and "conscious rationality" were infelicitous and contributed to part of the opposition his theory met in the Harvard group. He indicates that he should have clarified that by the term 'conscious' he also included subconscious behavior such as those implied by automatization of often repeated actions, as for instance, the solving of differential equations, in a mechanical manner, by an experimented mathematician. (Schumpeter [1940] $1991 \mathrm{fn.} \mathrm{4,} \mathrm{327)}$

${ }^{16}$ This distinction (between objective and subjective rationality) makes Schumpeter's conception of rationality in the social sciences different from both Parsons and Schütz. Schumpeter is however closer to Parsons that he is to Schütz inasmuch as Parsons "fails sufficiently to differentiate the attitude of science from that of the practical actor in the life-world. For Schütz there is a considerable more pronounced discontinuity than there is for Parsons between the 'rationality' of science (natural or social) and the 'rationality' of the day to day conduct, which is geared to different relevances or interests than those which concern the scientist.” (Gidddens, 1979, 684). Indeed according to Schütz, "in a theoretical system, therefore, only pure rational types are admitted.” (Schütz, 1943, 148).

${ }^{17}$ This Figure is a slightly modified reproduction of Swedberg (2001), who inserts this figure used by Schumpeter in a talk he gave on "rationality in economics" on October 27 and November 13, 1939.

${ }^{18}$ The argument should be qualified in the light of the Schumpeter' footnote concerning subjective rationality and conscious rationality (op. cit., see footnote 9 in this article)

${ }^{19}$ It is not to say that classes do have aims and behave as such but that individuals can follow some aims and interests that do not conform their own. We will be more precise about this below.

${ }^{20}$ See Festré and Nasica 2006, forthcoming.

21 “[w]e see, therefore, that families do surmount class barriers, as individuals rather than as a class - though quite often in groups - and that they do this in a manner which we can, even today, study in a sufficient number of individual cases, as well as in all important groups of cases.” (Schumpeter (1991 [1927], 251)

22 “[o]nly the physical individual, not the family, is class-born.” (Schumpeter (1991 [1927], 252)

23 “[t]his has always been the case, but never so much as in the world of capitalism.” (Schumpeter (1991 [1927], 253)

${ }^{24}$ In Schumpeter (1991 [1927]), we find some development concerning the inheritance of mental characteristics: "[a]s for mental characteristics, we have as yet only data in the field of defects, though these are in a state of fruitful evolution. For obvious reasons, it is difficult and dangerous to go beyond them, in the field of statistics as well as genealogy. Again, therefore, we emphasize that while it may be hopeless to pass considered judgement 
significance of a class - and incidentally, on most other basic questions of the social order, past or future - until this point has been settled, the basic idea of the class theory here presented is quite independent of it." (Schumpeter 1991 [1927], 216). This statement by Schumpeter can be explained by his reluctance to introduce some psychological arguments in his class theory as well as in his theory of economic evolution.

${ }^{25}$ This aspect sounds close to the Marxian assumption that social 'superstructure' is determined by economic 'infrastructure’.

${ }^{26}$ We refer here to the opposition between punctuated equilibrium vs. gradualism (see N. Eldredge and S.J. Gould 1972).

${ }^{27}$ See, for instance, Young (1996).

${ }^{28}$ See R. Arena and A. Festré $(2002,650)$.

${ }^{29}$ The three chacrateristics of holism are: “1) Society is the 'whole' which is more than its parts (holism), 2)

'Society’ affects the individual's aims (collectivism), 3) The social set-up influences and constrains the individual's behavior (institutional analysis)”. Individualism is characterized by: “1) Only individuals have aims and interests (individualism), 2) The individuals behave in a way adequate to their aim, given the circumstances (rationality principles), 3) The social set-up is changeable as a result of individuals' action (institutional reform).” (Agassi, 1975, 146). Agassi remarkably shows that these characteristics alone are not contradictory. In a similar way he shows that in order for Institutionalism and Psychologism to contradict one needs to add the following proposition: "Either society is primary, or individual is primary, but not both" (ibid, 149). He shows that this last proposition is inacceptable.

${ }^{30}$ They act in the sense that they define a set of constraints (see the previous note)

${ }^{31}$ Zafirovski (2003) shows that Schumpeter is one of the possible inspirers of a 'Unified Non-Rationalist Model of Social Action'.

${ }^{32}$ These criteria have been provided by Becker and Knudsen (2004) by way of inference from Schumpeter’s 1928 article.

${ }^{33}$ Commenting Pareto’s works in economics and sociology, Schumpeter wrote that “[t]he fundamental principle that what individuals, groups, and nations actually do must find its explanation in something much deeper than the creeds and slogans that are used in order to verbalize action, conveys a lesson of which modern men - and none more than we economists - stand much in need.” (Schumpeter, 1949, 172). 


\section{References}

Agassi, J. 1975. Institutional Individualism. The British Journal of Sociology 26(2):144-155.

Alchian, A.A. 1950. Uncertainty, Evolution and Economic Theory. Journal of Political Economy 28:211-21.

Arena, R. 1992. Schumpeter after Walras: ‘économie pure’ or 'stylized facts’? In Perspectives on the History of Economic Thought (vol. 7), edited by T. Lowry. Aldershot: Edward Elgar.

Arena, R. 2006. Economic rationality and the emergence of institutions: a Schumpeterian view, Contribution to the $\mathrm{XI}^{\text {th }}$ International Conference of the 'Schumpeter Society', Sophia Antipolis (France), 22-24 June 2006.

Arena, R., and A. Festré. 2006. Knowledge and Beliefs in Economics: The Case of the Austrian Tradition. In Knowledge and Beliefs in Economics, edited by R. Arena and A. Festré. Aldershot: Edward Elgar.

Becker, M., and T. Knudsen. 2003. Joseph A. Schumpeter: Unternehmer. Translation. Advances in Austrian Economics 6:235-266.

Becker, M., and T. Knudsen. 2004. The role of entrepreneurship in economic and technological development: the contribution of Schumpeter to understanding entrepreneurship. Working Paper.

Donzelli, F. 1983. Schumpeter e the teoria economica neoclassica. Ricercche Economiche 37(4):634-90.

Eldredge, N. and Gould, S.J. 1972. Ponctuated equilibrium: an alternative to phyletic gradualism. In Models in paleobiology, edited by T.J.M. Schopf . San Francisco: Cooper \& Co, pp. 82-115. 
Festré, A. 2006. The role of knowledge and beliefs in Economics: Menger and Wieser. Contribution to the $3^{\text {rd }}$ Annual STOREP Conference, Lecce (Italy), 1-3 June 2006.

Festré, A., and E. Nasica. 2006. Banks, credit, and the financial system in Schumpeter: an institutionalist perspective, forthcoming in European Journal of the History of Economic Thought 2009 16(2).

Friedman, M. 1953. Essays in Positive Economics. Chicago: The University of Chicago Press.

Gonçalves Da Silva, M. F. 2002. A Epistemologia da Economia Téorica em Schumpeter. Revista de Economia Politica 22(1):109-130

Garrouste, P. 2006. Morgenstern (1935) and Schumpeter (1940) on rationality. Mimeo, ATOM, University Paris 1-Panthéon Sorbonne.

Giddens, A. 1979. Schütz and Parsons: Problems of Meaning and Subjectivity. Contemporary Sociology 8(5):682-685

Hansen, N. M. 1966. Schumpeter and Max Weber: Comment. The Quarterly Journal of Economics 80(3):488-491

Hayek, F.A. 1937. Economics and Knowledge. Economica 4(13):33-54

Hayek, F.A. 1992. The Fortunes of Liberalism: Essays on Austrian Economics and the Ideal of Freedom (P.E. Klein, ed.). London: Routledge.

MacDonald, R. 1965. Schumpeter and Max Weber - Central Visions and Social Theories. The Quarterly Journal of Economics 79(3):373-396

Machlup; F. 1951. Schumpeter's Economic Methodology. The Review of Economics and Statistics 33(2):145-151

Menger, C. 1883. Untersuchung über die Methode der Sozialwissenschaft und der Politischen Oekonomie insbesondere. English translation: Problems of Economics and Sociology. Urbana: University of Illinois Press (1963). 
Parsons, T. 1937. The Structure of Social Action. Glencoe : Free Press

Perroux, F. 1935. Introduction à la traduction française de la Théorie de l'Evolution Economique de J.A. Schumpeter (Introduction to the French translation of J.A. Schumpeter's Theory of Economic Development). Paris: Dalloz.

Powell, W.W. 1996. Weber and Schumpeter: turbulent lives, ideas never at rest. Industrial and Corporate Change 5(3):917-924.

Santanelli, E., and E. Pesciarelli. 1990. The emergence of a vision: the development of Schumpeter's theory of entrepreneurship, History of Political Economy 22(4):677-96.

Schumpeter, J.A. 1908. Das Wesen und der Hauptinhalt der theoretischen Nationalökonomie. Munich and Leipzig: Dunker and Humblot.

Schumpeter, J.A. [1919] 1951. Zur Soziologie der Imperialism. Archiv für Sozialwissenschaft und Sozialpolitik 46:1-39. Translated into English as 'The sociology of imperialisms' in J.A. Schumpeter 1951.

Schumpeter, J.A. [1927] 1951. Die sozialen Klassen im ethnisch homogen Milieu”, Archiv für Sozialwissenschaft und Sozialpolitik 57: 1-67. Translated into English as "Social classes in an ethnically homogenous environment” in J.A. Schumpeter 1951. Also reprinted in Swedberg 1991.

Schumpeter, J.A. 1928. Unternehmer. In Handwörterbuch der Staatswissenschaften (4 ${ }^{\text {th }}$ ed). Jena: Verlag von G. Fisher 8:476-87. Translated into English as "Entrepreneur” by M. Becker and T. Knudsen 2003.

Schumpeter, J.A. 1934. The Theory of Economic Development: An Inquiry into Profits, Capital, Credit, Interest and the Business Cycle. Cambridge: Cambridge University Press.

Schumpeter, J.A. 1940. “The Meaning of Rationality in the Social Sciences”, reprinted in Swedberg (1991). 
Schumpeter, J.A. 1949. Vilfredo Pareto (1848-1923). The Quarterly Journal of Economics 63(2):147-173

Schumpeter, J.A. 1950. Capitalism, Socialism and Democracy, $3^{\text {rd }}$ edn. London: Allen \& Unwin. $1^{\text {st }}$ edn. New York: Harper, 1942.

Schumpeter, J.A. 1951. Imperialism and Social Classes, edited by P. Sweezy. New York: Augustus M. Kelley.

Schumpeter, J.A. 1954. History of Economic Analysis. London: Allen \& Unwin.

Schütz, A. 1943. The Problem of Rationality in the Social World. Economica 10(38):130-149

Shionoya, Y. 1991. Schumpeter on Schmoller and Weber: a methodology of economic sociology. History of Political Economy 23(2).

Shionoya, Y. 1997. Schumpeter and the Idea of Social Science: A Metatheoretical Study. Cambridge: Cambridge University Press.

Swedberg, R. 1991. Schumpeter J.A.: The Economics and Sociology of Capitalism. Princeton: Princeton University Press.

Swedberg, R. 2006. On teasing out sociology from economics. The American Journal of Economics and Sociology 65(1):71-4.

Wieser F. 1926. Das Gesetz der Macht. Vienna: Julius Springer. English Translation: The Law of Power. Bureau of Business Research, University of Nebraska-Lincoln (1983).

Young, H.P. 1996. The economics of conventions. Journal of Economic Perspectives 10(2):105-22.

Zafirovski, M. 2003. Human Rational Behavior and Economic Rationality. Electronic Journal of Sociology http://www.sociology.org/content/vol7.2/02_zafirovski.html 

